\title{
Divers' lung function: small airways disease?
}

\author{
Einar Thorsen, Kåre Segadal, Brit Kambestad, Amund Gulsvik
}

\begin{abstract}
Pulmonary function was measured in 152 professional saturation divers and in a matched control group of 106 subjects. Static lung volumes, dynamic lung volumes and flows, transfer factor for carbon monoxide $\left(\mathrm{T}_{\mathrm{c}}\right)$, transfer volume per unit alveolar volume $\left(K_{\infty}\right)$, delta- $\mathbf{N}_{2}$, and closing volume (CV) were measured and compared with reference values from recent Scandinavian studies, British submariners, and the European Community for Coal and Steel (ECCS) recommended reference values. Diving exposure was assessed as years of diving experience, total number of days in saturation and depth, and as the product of days in saturation and mean depth. Divers had significantly lower values for forced expired volume in one second $\left(F E V_{1}\right)$, $\mathrm{FEV}_{1} /$ forced vital capacity (FVC) ratio, $\mathrm{FEF}_{25-75 \%}, \mathrm{FEF}_{75-85 \%}, \mathrm{FEF}_{50 \%}, \mathrm{FEF}_{75 \%}, \mathrm{Tl}_{c 0}$, and $\mathrm{K}_{\infty}$ compared with the controls and a significantly higher CV. There was a positive correlation between diving exposure and $\mathrm{CV}$, whereas the other variables had negative correlations with diving exposure. Values for the control group were not different from the predictive values of Scandinavian reference studies or British submariners, although the ECCS standard predicted significantly lower values for the lung function variables both in divers and the control group. The pattern of the differences in lung function variables between the divers and controls is consistent with small airways dysfunction and with the transient changes in lung function found immediately after a single saturation dive. The association between reduced pulmonary function and previous diving exposure further indicates the presence of cumulative long term effects of diving on pulmonary function.
\end{abstract}

Previous studies have shown that divers in general have larger than predicted vital capacities compared

Norwegian Underwater Technology Centre A/S (NUTEC), N-5034 Ytre Laksevåg and Department of Thoracic Medicine, University of Bergen, Norway E Thorsen, K Segadal, B Kambestad, A Gulsvik with a standard reference population. ${ }^{1-3}$ Possible development of bronchial obstruction in divers has been questioned in these studies because the forced expired volume in one second $\left(\mathrm{FEV}_{1}\right) /$ forced vital capacity (FVC) ratio was lower than predicted, and in one study the forced expiratory flow rate (FEF) at $75 \%$ of $F V C$ expired $\left(\mathrm{FEF}_{75^{\circ}}\right)$ was also shown to be lower than predicted. ${ }^{1}$ This pattern of changes may result from the larger than predicted vital capacity, as there is a negative correlation between FVC and $\mathrm{FEV}_{1} / \mathrm{FVC}$ ratio, ${ }^{4}$ and thereby a result of respiratory muscle training because of breathing dense gases, or simply a result of the selection process of divers. There is a thorough screening of divers for cardiopulmonary disorders both at the start of their education and by annual medical examinations in both Norway and Britain. Effects of a single deep dive on pulmonary function, however, have been shown in several studies. ${ }^{5-8} \mathrm{~A}$ reduction in transfer factor for carbon monoxide $\left(\mathrm{Tl}_{c o}\right)$ is the most consistent effect reported. A small increase in vital capacity is often, but not always seen, and in two studies an increase in residual volume and total lung capacity was found. ${ }^{67}$ Gas exchange abnormalities, changes in ventilatory requirements and physiological dead space induced by exercise have been shown after diving to 360 metres of sea water (msw) ${ }^{8}$ Exposure to raised partial pressure of oxygen and venous gas microembolism during decompression both contribute as aetiological factors for the changes. The changes are reversible and seem to normalise within four to six weeks, but the possibility of a cumulative long term effect on pulmonary function remains.

In this study pulmonary function was measured in a group of professional saturation divers. The results were compared with both a matched control group and established reference values, and the effects of diving exposure on the lung function variables were analysed.

\section{Methods}

THE DIVERS

In 1988 there were 294 Norwegian saturation divers registered by the Norwegian Petroleum Directorate. At that time 106 of these were employed by the four Norwegian diving companies and these were invited by letter to participate in the study. The secondary response was $72 \%$ (76 divers). In addition, all other 
Table 1 Mean anthropometric data (SD) and smoking habits of divers and control group

\begin{tabular}{lllll}
\hline & $\begin{array}{l}\text { No of } \\
\text { subjects }\end{array}$ & Age $(y)$ & Height $(\mathrm{cm})$ & $\begin{array}{l}\text { Smokers } \\
\text { (fraction) }\end{array}$ \\
\hline Divers & 152 & $33 \cdot 2(5 \cdot 5)$ & $180 \cdot 2(5 \cdot 2)$ & $0 \cdot 30$ \\
Controls & 102 & $32 \cdot 7(5 \cdot 5)$ & $181 \cdot 3(5 \cdot 0)$ & $0 \cdot 29$ \\
\hline
\end{tabular}

saturation divers examined in screening programmes for selection of divers for experimental and operational dives by the Norwegian Underwater Technology Centre in the period 1984-7 were included. A total of 152 divers was finally examined. Seventeen divers had participated in deep experimental dives to $300-500 \mathrm{msw}$ before inclusion in this study and 43 have later participated in such dives. ${ }^{78}$ There were 51 British and 101 Norwegian divers. Nineteen divers were experienced in hyperbaric welding in dry habitats. Seventy nine were trained and served as divers in the Navy; the others were trained at various diving schools in Norway or Britain. Table 1 gives their age, height, and smoking habits. Ex-smokers were classified as non-smokers if they had stopped smoking for more than one year, otherwise as smokers. When available, the data on diving experience were collected from their log books; otherwise as the divers themselves could recall it. The maximum depth they had ever been to, their experience as professional divers, their experience as saturation divers (both in years), and the total number of days in saturation were recorded. The mean depth they usually were diving at was also recorded and the product of mean depth and total number of days in saturation was calculated.

\section{THE CONTROLS}

One hundred and six control subjects who had never dived, either professionally or for sport, were examined. They were recruited from the offshore staff of the local oil companies and local police corps by advertising. The first group comprised workers on offshore installations, seamen on diving vessels, and personnel qualified for such work but at the moment positioned in jobs onshore. Common to all was that they fulfilled the criteria for medical fitness for offshore workers issued by the Norwegian Directorate of Public Health. The other prerequisites for inclusion in the control group were that they were within the age group 20-50 and that they had not had any previous serious heart or lung disease. There were 49 policemen and 57 offshore workers. Four subjects in the control group were excluded because of symptoms of chronic bronchitis and an $\mathrm{FEV}_{1} / \mathrm{FVC}$ ratio below $70 \%$. The remaining 102 subjects all fulfilled the criteria for cardiopulmonary fitness required for diving issued by the Norwegian Directorate for Public Health, which states that $\mathrm{FEV}_{1}$ /
FVC ratio shall be higher than $70 \%$ in divers. Table 1 gives their age, height, and smoking habits.

\section{PULMONARY FUNCTION}

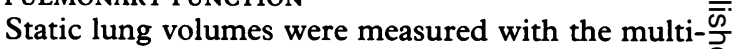
breath nitrogen washout technique from functional $\stackrel{\otimes}{\varrho}$ residual capacity (FRC). Combined with the measurements of expiratory reserve volume (ERV) $\overrightarrow{0}$ and inspiratory vital capacity (IVC) total lung. capacity (TLC) and residual volume (RV) were $\vec{\omega}$ calculated. Dynamic lung volumes were measured by $\stackrel{\odot}{\circ}$ at least three satisfactory forced expiratory man- $\mathbb{\Phi}$ oeuvres from total lung capacity in the sitting posi- 3 tion. The FVC, $\mathrm{FEV}_{1}$, and peak expiratory flow rate $\vec{A}$ $(\mathrm{PEF})$ were taken as the highest readings obtained. 0 The forced mean midexpiratory flow rate $\left(\mathrm{FEF}_{25-75^{\circ}}\right)$ ) and FEF rates at $50 \%$ and $75 \%$ of FVC expired

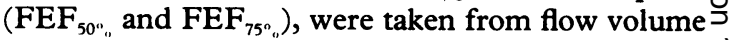
curves not differing by more than $5 \%$ from the $\overrightarrow{-}$ highest FVC. Measurement of $\mathrm{Tl}_{\mathrm{CO}}$ was by the single breath holding method. Effective alveolar volume $\frac{C}{c}$ $\left(\mathrm{V}_{\mathrm{A}}\right)$ was measured simultaneously by helium dilution and transfer per unit alveolar volume calculated $\vec{\varphi}$ $\left(\mathrm{K}_{\mathrm{CO}}\right){ }^{9}$ Closing volume (CV) and delta- $\mathrm{N}_{2}$ were? measured by the single breath $\mathrm{O}_{2}$ test. $^{10}$ The measurements were taken in the morning at least two hours after breakfast without tea or coffee, and with no smoking for two hours before the measurements. The measurements were taken on a Gould 1000 IV $\mathbb{D}$ computerised pulmonary function laboratory. Volume and test gas calibrations were carried out before each test and the results were corrected to the BTPS condition. The divers were examined at least two weeks after their last saturation dive. All subjects gave informed consent.

The selected reference values used for comparison with the results were those from a cross sectional $\frac{5}{3}$ survey of the general population of Oslo where the predicted values were based on an asymptomatic $\frac{O}{3}$ subsample of the population. ${ }^{11}$ Reference values for FVC, $\mathrm{FEV}_{1}$, and $\mathrm{FEF}_{25-75^{\circ}}$ are given. The study of $\frac{}{3}$ Salorinne $^{12}$ covers a sample of visitors to a Finnish $D$ tuberculosis dispensary, free of pulmonary disease, and with no exposure to dusts or respiratory irritants, N and separate reference values are given for smokers

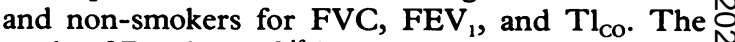
study of Brooks et al ${ }^{13}$ is a screening of British navy $\mathrm{\omega}$ submariners and submariner candidates and gives reference values for non-smokers, different smoking $\bullet$ categories, and all categories for FVC, $\mathrm{FEV}_{1}$, and $\Phi$ $\mathrm{FEF}_{75-85^{\circ} \circ}$. This study was chosen because it deals $\stackrel{\mathcal{f}}{-}$ with a selected group in the same age range as the 0 present study. The recommended reference values of ECCS give predictions for all lung function variables $\stackrel{\square}{\mathscr{\leftrightarrow}}$ in the present study except $\mathrm{FEF}_{75-85 \%},{ }^{9}$ This is a $\stackrel{\mathbb{D}}{\mathbb{2}}$ common European standard comprising the average $\bar{q}$ of available studies from both Europe and America on caucasians. 
STATISTICS

Divers and controls were compared by unpaired $t$ test. A p value less than 0.05 was considered significant. Multiple linear regression analysis was used to find relevant correlations between the lung function variables and the explanatory variables. The method selected was a forward stepwise procedure including the explanatory variable with the highest partial correlation with the model from the previous step. The significance level for variables to be included in the model was 0.05 .

\section{Results}

There were no significant differences in age and height distributions or smoking habits between the divers and the control group (table 1). The maximum depth the divers had ever been to was on average 177 msw (range 70-500) and their mean experience as professional divers was 10.4 years (range 1-22). Their mean experience as saturation divers was $5 \cdot 4$ years (range 1-11) with a total number of days in saturation of 292 days (range 5-1100). Maximum depth and total number of days in saturation were log normally distributed. The distributions of the rest of the diving exposure indices were somewhat skewed to the right and did not adjust better to a log normal distribution.

\section{STATIC LUNG VOLUMES}

There were no significant differences between the groups in TLC, RV, or FRC (table 2). Positive correlations were found for TLC, RV, and RV/ TLC $\%$ with years of saturation diving experience $(\mathrm{p}<0.01)$. Closing volume was significantly higher
Table 2 Selected lung function variables (mean (SD)) in divers and control group

\begin{tabular}{|c|c|c|}
\hline & $\begin{array}{l}\text { Divers } \\
(n=152)\end{array}$ & $\begin{array}{l}\text { Controls } \\
(n=102)\end{array}$ \\
\hline $\begin{array}{l}\text { Static lung volumes: } \\
\text { IVC }(1) \\
\text { TLC }(1) \\
\text { RV (1) } \\
\text { FRC }(1) \\
\text { CV }(\%)\end{array}$ & $\begin{array}{c}5.94(0.62) \\
7.89(0.84) \\
1.91(0.43) \\
3.91(0.76) \\
12.60(2.66)^{\star}\end{array}$ & $\begin{array}{r}5.98(0.58) \\
7.87(0.86) \\
1.83(0.41) \\
4.10(0.75) \\
11.74(2.26)\end{array}$ \\
\hline 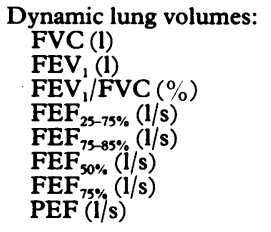 & $\begin{array}{c}5.94(0.68) \\
4.55(0.58)^{\star} \\
0.77(0.07)^{\star} \\
3.96(1.14)^{\star} \\
1.26(0.54)^{\star} \\
4.73(1.30)^{\star} \\
1.83(0.69)^{\star} \\
11.71(1.47)\end{array}$ & $\begin{array}{r}5.97(0.55) \\
4.85(0.45) \\
0.81(0.05) \\
4.86(1.01) \\
1.60(0.50) \\
5.75(1.20) \\
2.30(0.66) \\
12.12(1.26)\end{array}$ \\
\hline $\begin{array}{l}\text { Diffusion: } \\
\mathrm{Tl}_{\mathrm{c}}(\mathrm{mmol} / \mathrm{min} / \mathrm{kPa}) \\
\mathbf{K}_{\mathrm{co}}(\mathrm{mmol} / \mathrm{min} / \mathrm{kPa} / \mathrm{l}) \\
\mathbf{V}_{\mathbf{A}}(\mathbf{l})\end{array}$ & $\begin{array}{c}11.9(1.6)^{\star} \\
1.53(0.19)^{\star} \\
7.78(0.84)\end{array}$ & $\begin{array}{c}12.5(1.3) \\
1.61(0.20) \\
7.75(0.82)\end{array}$ \\
\hline
\end{tabular}

$\star$ Significantly different from controls $(p<0.01)$.

in divers $(\mathrm{p}<0.01)$ and correlated also with diving exposure measured as total number of days in saturation (table 3).

\section{DYNAMIC LUNG VOLUMES}

The $\mathrm{FEV}_{1}, \mathrm{FEV}_{1} / \mathrm{FVC}$ ratio, and the flow rates at given fractions of FVC expired were all significantly lower in divers compared with controls $(p<0.01)$ (table 2, figure). All indices showed a negative correlation with number of days in saturation (table 3). There was no difference in FVC between the divers, the controls, or the predicted values of the

Table 3 Regression coefficients for age, height, and indices of diving exposure on selected lung function variables. Only significant relations are given $(p<0 \cdot 01)$

\begin{tabular}{|c|c|c|c|c|c|c|c|}
\hline & Intercept & Age (y) & Height $(\mathrm{cm})$ & $\begin{array}{l}\text { Smoking } \\
(1=\text { yes, } 0=\text { no })\end{array}$ & $\begin{array}{l}\text { Saturation } \\
\text { diving } \\
\text { experience } \\
(y)\end{array}$ & $\begin{array}{l}\text { Time in } \\
\text { saturation } \\
\text { (ln/days) }\end{array}$ & $R^{2}$ \\
\hline $\begin{array}{l}\text { Static lung volumes: } \\
\text { IVC (1) } \\
\text { TLC (1) } \\
\text { RV (1) } \\
\text { FRC }(1) \\
\text { CV }(\%)\end{array}$ & $\begin{array}{r}-5 \cdot 75 \\
-10.61 \\
-4.56 \\
-8.96 \\
3.17\end{array}$ & $\begin{array}{r}-0.013 \\
-0.017 \\
-\quad 0.255\end{array}$ & $\begin{array}{r}0.067 \\
0.102 \\
0.032 \\
0.072 \\
-\end{array}$ & $\begin{array}{l}- \\
- \\
1.005\end{array}$ & $\begin{array}{l}- \\
0.028 \\
0.025 \\
-\end{array}$ & $\begin{array}{l}- \\
- \\
0.137\end{array}$ & $\begin{array}{l}0.35 \\
0.37 \\
0.24 \\
0.23 \\
0.42\end{array}$ \\
\hline 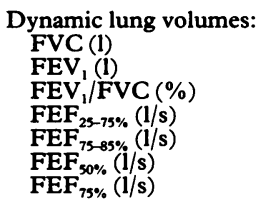 & $\begin{array}{r}-5.56 \\
-1.86 \\
121 \\
6.63 \\
-0.28 \\
7.02 \\
3.87\end{array}$ & $\begin{array}{l}-0.020 \\
-0.031 \\
-0.30 \\
-0.054 \\
-0.040 \\
-0.038 \\
-0.047\end{array}$ & $\begin{array}{c}0.067 \\
0.043 \\
-0.20 \\
-\quad 0.018 \\
-\quad\end{array}$ & $\begin{array}{l}-0.135 \\
- \\
- \\
- \\
-\end{array}$ & $\begin{array}{l}- \\
z \\
- \\
-\end{array}$ & $\begin{array}{l}-0.050 \\
-0.90 \\
-0.172 \\
-0.064 \\
-0.195 \\
-0.091\end{array}$ & $\begin{array}{l}0.35 \\
0.39 \\
0.22 \\
0.26 \\
0.35 \\
0.20 \\
0.30\end{array}$ \\
\hline $\begin{array}{l}\text { Diffusion: } \\
\mathrm{TL}_{\infty}(\mathrm{mmol} / \mathrm{min} / \mathrm{kPa}) \\
\mathrm{K}_{\infty}(\mathrm{mmol} / \mathrm{min} / \mathrm{kPa} / \mathrm{l})\end{array}$ & $\begin{array}{r}-6 \cdot 11 \\
1 \cdot 94\end{array}$ & $\begin{array}{l}-0.068 \\
-0.009\end{array}$ & $-^{0 \cdot 116}$ & $\begin{array}{l}-0.842 \\
-0.116\end{array}$ & - & $\begin{array}{l}-0.078 \\
-0.011\end{array}$ & $\begin{array}{l}0.33 \\
0 \cdot 20\end{array}$ \\
\hline
\end{tabular}

«ln = Natural logarithm 
Table $4 F V C, F E V_{1}, F E F_{25-75 \%}$, and $T l_{c o}$ in divers and controls adjusted for age and height, compared with selected reference studies

\begin{tabular}{|c|c|c|c|c|c|c|}
\hline & Divers & Controls & Gulsvik" & Salorinne ${ }^{12}$ & Brooks et $a^{13}$ & ECCS \\
\hline $\begin{array}{l}\text { FVC (1) } \\
\text { FEV }_{1}(1) \\
\mathrm{FEF}_{25-75 \%}(1 / \mathrm{s}) \\
\mathrm{Tl}_{\infty}(\mathrm{mmol} / \mathrm{min} / \mathrm{kPa})\end{array}$ & $\begin{array}{r}5.94 \\
4.55 \\
3.96 \\
11.9\end{array}$ & $\begin{array}{c}5 \cdot 98 \\
4 \cdot 85 \\
4 \cdot 86 \\
12 \cdot 5\end{array}$ & $\begin{array}{l}5 \cdot 82 \\
4 \cdot 78 \\
5 \cdot 00 \\
-\end{array}$ & $\begin{array}{l}5 \cdot 89 \\
4 \cdot 94 \\
-11 \cdot 5\end{array}$ & $\begin{array}{l}5 \cdot 98 \\
4 \cdot 71 \\
- \\
-\end{array}$ & $\begin{array}{r}5 \cdot 17 \\
4 \cdot 29 \\
4 \cdot 77 \\
11 \cdot 9\end{array}$ \\
\hline
\end{tabular}

Scandinavian studies or British submariners, but the ECCS recommended reference value was significantly lower (table 4). The $\mathrm{FEV}_{1}$ in divers was significantly lower than in controls, and Scandinavian and British submariners, but higher than that predicted by the ECCS standard. The $\mathrm{FEF}_{25-75 \%}$ was also lower in divers compared with that for the controls and for that quoted in the reference studies.

\section{DIFFUSION CAPACITY}

Divers had significantly lower $T l_{c o}$ and $K_{c o}$ compared with controls $\left(p<0.01\right.$ ), whereas $V_{A}$ was not different. Negative correlations were found for $T l_{c o}$ and $\mathrm{K}_{\mathrm{co}}$ with number of days in saturation. Compared with the reference studies, our control group had significantly higher values than predicted by ECCS and Salorinne, ${ }^{12}$ whereas the values for divers did not differ from the values reported from those studies.

There were no significant differences in lung function variables between Norwegian and British divers or between divers experienced in hyperbaric welding and those not. The divers with military experience did not differ from those without such experience, and the 76 divers who responded to the invitation to participate in the study did not differ from those examined in the screening programmes.

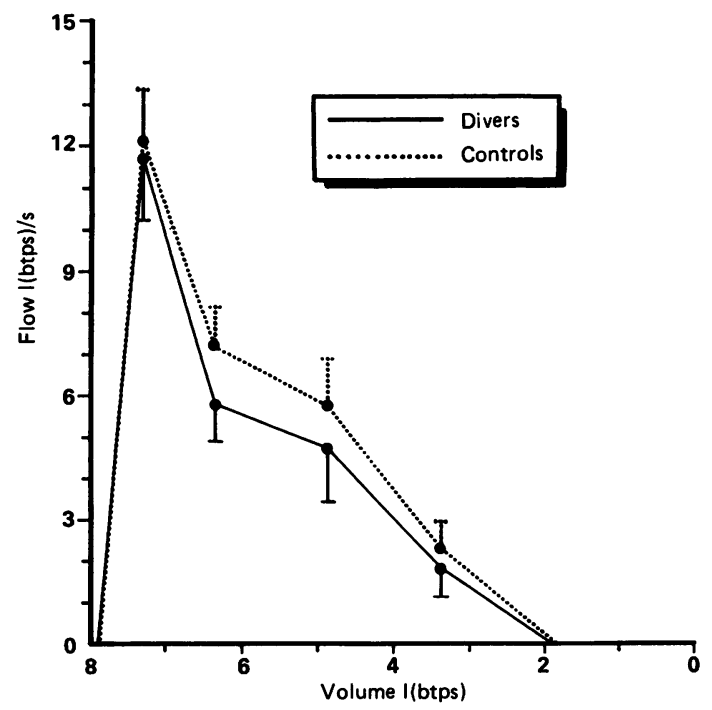

Flow volume loops in divers and controls

\section{Discussion}

Divers are a selected group with respect to cardiopul- $\stackrel{\mathscr{\omega}}{\circ}$

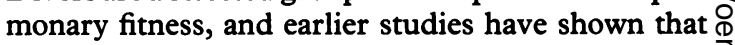
when compared with reference values for a general $?$ population, divers have larger than predicted lung volumes. ${ }^{1-3}$ When a control group is not specific for $i$ the population studied, large changes in pulmonary $\vec{G}$ function can take place without being detected. The selection criteria for divers are the same as those for $\triangle$ submariners with respect to pulmonary function and $\overrightarrow{ }$ the policemen and offshore workers in our control group were selected on a basis of general medical fitness. Neither submariners nor the control group of $\stackrel{\text { ? }}{\rightarrow}$ this study differ from recent Scandinavian studies on $\vec{\vartheta}$ random samples of the population concerning the FVC, $\mathrm{FEV}_{1}$, and $\mathrm{FEF}_{25-75 \%}$. Our control group should, therefore, be adequate for comparison with divers, as should the predictive values of Gulsvik, ${ }^{11}$ Salorinne, ${ }^{12}$ and Brooks et $a l^{13}$ for FVC, FEV ${ }_{1}$, and $\mathrm{FEF}_{25-75^{\circ} \text {. }}$ The ECCS standard for FVC and FEV $\frac{\mathbb{\Phi}}{\mathbb{Q}}$ differs significantly from that for the divers, the control group, and the other reference studies.

The response of the divers invited to take part in our study was rather low ( $72 \%$ secondary response), and this may have resulted in a healthy worker effect. The group of divers examined in the screening $\Phi$ programmes for experimental dives was probably also influenced by this effect as the diving companies usually carried out a preliminary screening of their divers before these projects. It was also known that $\frac{O}{3}$ all those invited were actively employed as divers, and minimum requirements for pulmonary function are then necessary. Inclusion of the non-responders $\frac{D}{2}$ would thus probably not have affected the results. The control group was, by its selection, a healthy N worker group. This group did not differ significantly from reference values representative of their population.

In diving, the lungs are exposed to several factors 0 that can induce changes in pulmonary function. 0 Under pressure they are exposed to an artificial $\Phi$ atmosphere with a high gas density resulting in ? increased work of breathing. ${ }^{14}$ Raised partial pressure $T$ of oxygen has a well documented toxic pulmonary effect, ${ }^{15}$ and venous microemboli filtered in the $\stackrel{\odot}{\Phi}$ pulmonary circulation during decompression can $\underset{\mathbb{Q}}{\stackrel{2}{2}}$ also produce inflammation and gas exchange abnor- 0 malities. ${ }^{81617}$ Venous microbubbles have frequently been found in operational diving even though the 
decompressions had been carried out according to accepted decompression tables, and the divers showed no signs of clinical decompression sickness. ${ }^{18}$ If special tasks such as welding are carried out by the divers they may also be exposed to toxic pollutants from this process if adequate respiratory protection is not used.

The divers had reduced dynamic lung volumes and flows, reduced diffusion capacity, and increased CV compared with controls; with the largest reductions in maximal flow rates at low lung volumes. This is a characteristic pattern of "small airways dysfunction." A correlation between the lung function variables and diving exposure was also shown. The measurements of dynamic lung volumes, $\mathrm{Tl}_{\mathrm{co}}$, and $\mathrm{CV}$ are done independently of each other and the correlations with diving exposure were all in a direction that is consistent with a specific pathophysiological disorder of the lungs.

It is difficult to estimate the total dose of exposure to the factors known to induce changes in pulmonary function in diving. Different diving companies have different diving tables for use of partial pressures of oxygen in the breathing gas and different decompression procedures. The effect of hyperoxia on the lungs is time dose dependent and the bubble load on the pulmonary circulation is dependent on total time in decompression and decompression rates. Large individual variations in the liability for bubble formation also exists. ${ }^{8}$ It was not possible to explore the details of each diver's experience with respect to this because of lack of records, especially from the early years of the careers, which ranged up to 22 years. This exposure will, however, be reflected in the duration of their diving career, which was easily and accurately recorded. This was divided into years of diving experience, years of saturation diving experience, and total number of days in saturation. Years of diving experience and saturation diving experience were dependent on age, whereas number of days in saturation was not. The procedures of surface orientated air diving and saturation diving differ fundamentally, but how different diving practise will affect pulmonary function cannot be answered by this study. All the divers were also experienced with air diving, but no attempt was made to quantify this exposure.

Immediately after saturation dives, significant transient changes in pulmonary function have been shown. In two studies RV and TLC were increased. ${ }^{67}$ In one of these maximal flow rates at given absolute lung volumes were lower after the dives and CV was also increased. ${ }^{7}$ Most consistently a reduction in $\mathrm{Tl}_{\mathrm{co}}$ was reported. ${ }^{57}$ These represent changes similar to those between divers and controls in this study; a further indication that a cumulative long term effect of diving on pulmonary function is present. There is no evidence of adaptation to the hyperbaric environment with its increased gas density and increased work of breathing. A higher vital capacity in divers and a positive correlation with exposure would then have been expected.

This study was supported by Norsk Hydro A/S, Statoil, and The Royal Norwegian Council for Scientific and Industrial Research (NTNF).

We are grateful to the subjects participating in the study and to the Norwegian diving companies StoltNielsen Seaway, Subsea Dolphin, Oceaneering, and Aker Comex.

Requests for reprints to: Dr Einar Thorsen, NUTEC, Gravdalsveien 255, 5034 Ytre Laksevåg, Norway.

1 Crosbie WA, Reed JW, Clarke MC. Functional characteristics of the large lungs found in commercial divers. J Appl Physiol 1979;46:639-45.

2 Davey IS, Cotes JE, Reed JW. Relationship of ventilatory capacity to hyperbaric exposure in divers. $J$ Appl Physiol 1984;56:1655-8.

3 Watt $\mathrm{S}$. Effect of commercial diving on ventilatory function. $\mathrm{Br} J$ Ind Med 1985;42:59-62.

4 Bouhuys A, Beck GI. Large lungs in divers? J Appl Physiol 1979;47:1136.

5 Cotes JE, Davey JS, Reed JW, Rooks M. Respiratory effects of a single saturation dive to $300 \mathrm{~m}$. Br J Ind Med 1987;44:76-82.

6 Smith RM, Hong SK, Dressendorfer RH, Dwyer HJ, Hayashi E, Yelverton C. Hana Kai II: a 17 day dry saturation dive at 18.6 ATA. Cardiopulmonary functions. Undersea Biomed Res 1977;4:267-81.

7 Thorsen E, Segadal K, Myrseth E, Påsche A, Gulsvik A. Pulmonary mechanical function and diffusion capacity after deep saturation dives. $\mathrm{Br} J$ Ind Med 1990;47:242-7.

8 Thorsen E, Hjelle J, Segadal K, Gulsvik A. Exercise tolerance and pulmonary gas exchange after deep saturation dives. $J$ Appl Physiol (in press).

9 Quanjer PH, ed. Standardised lung function testing. Bull Europ Physiopathol Respir 1983;19:(suppl 5):7-10.

10 National Heart and Lung Institute. Suggested standardised procedures for closing volume determinations (nitrogen method). Bethesda: Division of Lung Diseases, National Heart and Lung Institute, 1973.

11 Gulsvik A. Obstructive lung disease in an urban population. Oslo: Reprografisk Industri A/S, 1979:88-120.

12 Salorinne $Y$. Single breath pulmonary diffusing capacity. Reference values and application in connective tissue diseases and in various lung diseases. Scandinavian Journal of Respiratory Disease 1976;(suppl 96):28-42.

13 Brooks GJ, Pethybridge RJ, Pearson RR. Lung function reference values for $\mathrm{FEV}_{1}, \mathrm{FVC} \mathrm{FEV}_{1} / \mathrm{FVC}_{\text {ratio }}$ and

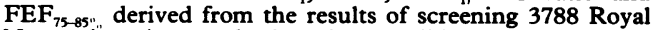
Navy submariners and submariner candidates by spirometry. In: Shields TG, Milne AH, eds. Proceedings of XIVth annual meeting of European Undersea Biomedical Society. Aberdeen 1988: European Undersea Biomedical Society, 1988: Chapter 13.

14 Maio DA, Fahri LE. Effect of gas density on mechanics of breathing. J Appl Physiol 1967;23:687-93.

15 Harabin AL, Homer LD, Weathersby PK, Flynn ET. An analysis of decrements in vital capacity as an index of pulmonary oxygen toxicity. $J$ Appl Physiol 1987;63:1130-5.

16 Hlastala MP, Robertson HT, Ross BK. Gas exchange abnormalities produced by venous gas emboli. Respir Physiol 1979;36:1-17.

17 Ohkuda K, Nakhara K, Binder A, Staub NC. Venous air emboli in sheep: reversible increase in lung microvascular permeability. J Appl Physiol 1981;49:887-94.

18 Spencer MP, Clark HF. Precordial monitoring of pulmonary gas embolism and decompression sickness. Aerospace Medicine 1972;43:762-7.

Accepted 5 February 1990 